\title{
Evaluation of water quality parameters of Valvan dam water for drinking purpose
}

\section{S. B. Patil ${ }^{1}$ and ${ }^{*}$ B. V. Patil ${ }^{2}$}

\author{
${ }^{1} \mathrm{HRM}$ College, RAJGURUNAGAR, PUNE. \\ ${ }^{2}$ Modern College of Arts, \\ Science and Commerce Shivajinagar, PUNE. \\ *Corresponding Author \\ Email : bvpatil09@gmail.com
}

Received : 25.03.2020; Revised : 30.04.2020; Accepted : 02.05.2020

\begin{abstract}
Water quality is becoming a global problem in developed and underdeveloped countries. Human activities directly or indirectly affect quality of water and pollute the water; the demand for fresh water is increasing faster. Therefore, in the present investigation attempt has been made to asses chemical parameters of Valwan dam water. Obtained values were compared with two standards of WHO and BIS. Parameters such as pH, Alkalinity, TDS, Total Hardness, $\mathrm{CO}_{2}$, dissolved oxygen, phosphate were found with permissible limits of BIS and WHO which indicates this water body is suitable for drinking purpose.

Figure : $00 \quad$ References : $17 \quad$ Table : 01

KEY WORDS : Alkalinity, Phosphate, Valvan dam, Water quality.
\end{abstract}

\section{Introduction}

Clean water is essential to human survival, and we directly or indirectly are dependent on continental water, including streams, lakes and ground water. Humans use about $54 \%$ of the runoff that is reasonably accessible. Thus, fresh water is important natural resource that will be limited severely with future growth of the human population and increases the standard of living. Therefore, the study of fresh water will lead to more sound decisions regarding aquatic habitats as well as provide a solid basis for future research ${ }^{11}$. The presence of dissolved oxygen is essential to maintain the higher forms of biological life and to keep the proper balance of various populations thus making the water body healthy. Free carbon dioxide in the waters accumulates due to microbial activity and respiration of organisms. This imparts the acidity to the waters because of the formation of carbonic acid. The phosphate is generally considered as the critical nutrient for the growth of algae in water. The enrichment of this nutrient leads to the process of eutrophication. Hardness is the property of water which increases the boiling point of waters. Hardness is temporary if it is associated mainly with carbonates and bicarbonates ${ }^{16}$. Total solids are the measure of the amount of all kinds of solids (suspended, dissolved, volatile etc.). Total dissolved solids denote mainly the various kinds of minerals present in water. The total suspended solids denote the suspended impurities present in the water. $\mathrm{pH}$ measures the hydrogen ion concentration in the water.

Study area. Valwan dam was constructed in the vicinity of fast growing city, namely Lonavala, in the state of Maharashtra, India. The dam supplies water to the Khopoli power station at the foothills of the Sahyadri for generating electricity. The Kundali River feeds into the dam's reservoir. The height of dam is $26.36 \mathrm{~m}$, length $1356 \mathrm{~m}$ and dam volume is $182,000 \mathrm{~m}^{3}$. And its gross storage capacity is $72,500,000.00 \mathrm{~m}^{3}$

\section{Material and Method}

The present study was carried out in the month of October 2018. The water samples were collected from the Valwan dam in container. The temperature and $\mathrm{pH}$ of water samples were recorded in the site itself. All other chemical parameters such as electric conductivity, total dissolved solids were estimated by standard methods ${ }^{10}$. Alkalinity, hardness, $\mathrm{O}_{2}, \mathrm{CO}_{2}$, phosphate, chloride were determined by titration method ${ }^{15}$.

\section{Observations}

To observe the water quality of Valwan Dam by analysing physical parameters and chemical parameters studies on Physico-chemical parameter values of Valwan Dam water show permissible values of standard WHO and BIS water quality ${ }^{1,15}$, but it needs to check for bacterial and plankton study. 
Evaluation of water quality parameters of Valvan dam water for drinking purpose

TABLE-1 : Physico-chemical properties of Valwan dam water in October 2018.

\begin{tabular}{|c|c|c|c|c|c|}
\hline \multirow[t]{2}{*}{ Parameters } & \multicolumn{2}{|c|}{$\begin{array}{l}\text { Bureau of Indian } \\
\text { std. (BIS) }\end{array}$} & \multirow[t]{2}{*}{ Observed value } & \multicolumn{2}{|c|}{ WHO (standard) } \\
\hline & Permissive & Excessive & & Permissive & Excessive \\
\hline Colour & 5 Hazen unit & 25 Hazen unit & Clear & & \\
\hline pH & $6.5-8.5$ & $6.5-9.2$ & 7.2 & $6.5-8.5$ & $6.5-8.5$ \\
\hline E.C.(mhos/cm) & 750 & 2000 & 142 & - & - \\
\hline TDS(mg/l) & 500 & 1000 & 120 & 500 & 1000 \\
\hline Total Hardness(mg/l) & 300 & 600 & 124 & 100 & 500 \\
\hline Alkalinity(mg/l) & 200 & 600 & 112 & 100 & 500 \\
\hline Phosphate(mg/l) & 0.25 & 0.40 & 0.82 & - & - \\
\hline Chloride(mg/l) & 250 & 1000 & 12.0 & 200 & 600 \\
\hline $\mathbf{O}_{2}(\mathrm{mg} / \mathrm{l})$ & 5 & - & 7.3 & - & - \\
\hline $\mathrm{CO}_{2}(\mathrm{mg} / \mathrm{l})$ & - & - & 2.6 & - & - \\
\hline
\end{tabular}

\section{Result and Discussion}

Studies on chemical and physical parameters are depicted in Table-1. The observed values of these parameters compared with BIS and WHO standards. The water temperature was in a range of 15 to $21^{\circ} \mathrm{C}$. Aquatic life and physicochemical parameters of water bodies are affected by temperature.

The collected water samples were found to be odourless and it was showing slight bluish green colour.The $\mathrm{pH}$ of the sample recorded at the site was found slightly alkaline (7.2) it is within the permissive range of $\mathrm{BIS}$ and $\mathrm{WHO}^{16}$. The higher values of $\mathrm{pH}$ reduced germicidal potential of chloride ${ }^{6}$. The optimum $\mathrm{pH}$ of water which favours the growth of fishes ranged from 6.5-9.5 and 6.5 to 8.4 congruently 9,13 . The values observed for electrical conductivity was in the range of 142 micromhos/ $\mathrm{cm}^{2}$. Conductivity varies seasonally due to evaporation, it is higher during summer while it is low during rainy season due to dilution of water. Increasing conductivity values suddenly indicate presence of pollutant to the water ${ }^{14}$. Total dissolved solid indicates organic and inorganic matter in the sample. The observed value in present investigation was $(120 \mathrm{mg} / \mathrm{l})$ in permissible range of BIS and WHO. High concentration of total dissolved solids affects fresh water organisms, reduces gases solubility, drinking water quality and irrigation purpose ${ }^{2}$.

Dissolved oxygen shows diurnal fluctuation, low at night and high in the afternoon. It is evolved during photosynthesis and removed from the water through respiration and decomposition ${ }^{5}$. The observed values for DO $(7.3 \mathrm{mg} / \mathrm{l})$ indicates efficiency of photosynthesis of aquatic life potential for water quality. DO is essential for respiration, it helps to breakdown organic detritus ${ }^{2}$. Lower value of carbon dioxide $(2.6 \mathrm{mg} / \mathrm{l})$ was recorded during the present investigation. Lower values of carbon dioxide during winter season related to low temperature resulting decrease in rate of decomposition ${ }^{5}$. On the other hand higher values of $\mathrm{pH}$ during winter season may be due to lower values of carbon dioxide. Higher values of $\mathrm{pH}$ also recorded in winter season ${ }^{13}$. Higher values of carbon dioxide noted during summer season ${ }^{3}$. Buffering capacities of water represents Alkalinity; high alkalinity values are indicative of the eutrophic nature of the water bodies, and not suitable for ecosystem as well as for 
potable use. The weathering of rocks is the potential source of alkalinity. Alkalinity is due to the presence of bicarbonates, carbonates or hydroxides ${ }^{15}$. The value of alkalinity studied for the sample was (112 mg/l) within permissible limit of $\mathrm{WHO}$ and BIS standard ${ }^{1,17}$. Hardness of the water is due to presence of calcium and magnesium ions. Water containing hardness concentration up to $60 \mathrm{mg} / \mathrm{lit}$ are called 'soft' water and those containing 120-180 mg/lit as 'hard' water'. Excess of hardness is not suitable for potable water. The hardness value of sample was $(124 \mathrm{mg} / \mathrm{l})$ in the desirable limits. The chloride content in the present water sample was (12 $\mathrm{mg} / \mathrm{l})$ which is found to be very well within the desirable limits of WHO and BIS. Excess of chloride in water imparts salty taste and the people those who are not accustomed to high chloride are subjected to laxative effect $^{12}$. Chlorides observed during month of October to February were in the range of $16.0-60.05 \mathrm{mg} / \mathrm{l}$ which correlates with the present investigation ${ }^{8}$.

\section{Conclusion}

The present study of water samples for chemical and physical parameters such as $\mathrm{pH}$, Alkalinity, Hardness, Chloride, $\mathrm{CO}_{2}, \mathrm{O}_{2}$, Total dissolved solid, and Electric conductivity were found to be within the permissible limits of BIS and WHO for drinking purpose. The preliminary studies on zooplankton and phytoplankton reflex their presence. Therefore, this water can be used for drinking purpose only after suitable treatment of other impurities.

\section{References}

1. B.I.S. "Bureau of Indian Standards Drinking 30. Water specification", (second revision) 2015; ISS 10500.

2. Boyd CE, Tucker CS. Pond aquaculture water quality management. Kluwer Academic Publisher, London. 1998.

3. Devangee Shukla, Kinjal Bhadresha, Jain NK, Modi HA. IOSR Journal of Environmental Science, Toxicology And Food Technology (IOSR-JESTFT) 2013; e-ISSN: 2319-2402, p- ISSN: 2319-2399. 2013(Jul.-Aug.); 5 (3) : pp. 8992.

4. Dodds WK. Fresh water ecology concepts and environmental applications. 2002; published by Elsevier, a division of Reed Elsevier India Pvt. New Delhi 110024.

5. Goldman CR, Horne A.J. Limnology Mcgrow-Hill International book co. 1983; p. 464.

6. Kumar Arvind. Ecologica of Pollution Pragathi Prakashan, Meerut. 2002.

7. Patel NK, Sinha BK. Study of the pollution load in the pond of Burla area near Hirakund dam at Orissa. J. Env. Poll. 1998; 5 :157-160.

8. Prakash D Raut, et al. Study of physicochemical and biological characteristics of lakes from Shivaji University Campus, Kolhapur, Maharashtra. Pelagia Research Library. Advances in Applied Science Research. 2011; 2 (6): 505-519.

9. Priyanka T, Bajpai A, Thareja S. Evaluation of Water Quality: Physicochemical Characteristics of Ganga River at Kanpur by using Correlation Study", Nature and Science. 2009; 1(6).

10. Public Health Association (APHA). Standard methods for the examination of water and wastewater. $1999 ; 20$ ed.

11. Ratan N, Srivastava S, Pathak A, Sign UN. Islater quality of Parichha dam reservoir in relation to fisheries in Jhansi (UP) India. Flora and Fauna. 2017; 23 (1) : 95-98.

12. Raviprakash SL, Krishna Rao G. The chemistry of Ground water Paravada area with regard to their suitability for domestic and Irrigation purposes. Indian J. Geochem., 1989; 4(1):39-54.

13. Sharma VK. Ecological studies on macro benthic invertebrate of some ponds of Jammu. 1999; Ph.D. Thesis, University of Jammu, Jammu.

14. Singh SP, Deepa P, Rashmi S. Hydrobiological studies of two ponds of Satna (M.P.) India. International Journal of Environmental Research. 2002; 8(3): 289.

15. Trivedy RK, Goel PK. Chemical and Biological Methods for Water Pollution Studies," Environmental Publications, Karad, 1984; pp. 1-22.

16. Trivedy RK, Goel PK. Practical methods in Ecology and Environmental Science. 1989; Published by Enviro Media, Post Box 60, Karad 415110, India.

17. World Health Organization (WHO). Guidelines for drinking water quality. 2011. 